\title{
O DISCURSO DO ÓDIO, O DIREITO E A DEMOCRACIA
}

\author{
Cleyson de Moraes Mello ${ }^{1}$ \\ Antônio Celso Alves Pereira ${ }^{2}$
}

\section{Resumo}

O presente texto tem como finalidade à análise do Discurso do ódio na sociedade democrática, bem como sua concretização em diversos casos concretos no Brasil, nos Estados Unidos e na Corte Interamericana de Direitos Humanos. O objetivo é uma abordagem geral sobre o seu conceito e as justificativas pelas quais tal discurso é incompatível com uma sociedade plural, aberta e inclusiva.

Palavras-chave: Discurso Do Ódio; Democracia, Tolerância.

\section{INTRODUÇÃO}

Em sua instigante obra O Cultivo do Ódio - A experiência Burguesa da Rainha Vitória a Freud, Peter $\mathrm{Gay}^{3}$ ao analisar "as cicatrizes que o comportamento agressivo do ser humano deixou no rosto do passado", decorrente das guerras, da luta de classes, do choque entre grupos religiosos e étnicos, da luta pelo poder político e por ganhos econômicos e financeiros, bem como os ódios gerados pelo nacionalismo exacerbado, pelo imperialismo, os estragos do crime, os enfrentamentos da vida privada, "tudo isso - diz o historiador - é o um testemunho convincente de que a agressão forneceu a maior parte do combustível para a ação e a mudança histórica”. ${ }^{4}$

Procurar entender a origem, a natureza e as consequências e significados da agressividade humana tem sido, e sempre será, o objeto dos cientistas que estudam os estados e processos mentais, como também dos pesquisadores sociais e dos operadores do direito. Nessa linha, é importante evocar o pensamento de Theodore Zeldin, que, em sua obra História Íntima da Humanidade, discutindo sentimentos, como coragem e solidão, aponta a importância do medo individual ou coletivo na história da humanidade. Pessoas e grupos sociais,

\footnotetext{
${ }^{1}$ Doutor em Direito. Professor Adjunto da Faculdade de Direito da UERJ. Departamento de Teorias e Fundamento do Direito. Diretor Adjunto da Faculdade de Direito de Valença - RJ. Professor Titular da Universidade Estácio de Sá - Rio de Janeiro Brasil. E-mail: profcleysonmello@hotmail.com

${ }^{2}$ Professor do Programa de Pós-Graduação em Direito da Universidade Veiga de Almeida. E-mail: acelsopereira@globo.com

${ }^{3}$ Peter Gay (1923-2015), historiador e humanista alemão, professor emérito da Universidade de Yale, dedicou grande parte de sua vida ao estudo do Iluminismo, entretanto, nos anos finais de sua vida elegeu o período vitoriano como objeto central de suas preocupações intelectuais. Além disto, é autor da mais importante biografia de Freud.
} 
segundo afirma, tão logo se livram de um medo, elegem outro imediatamente. Diz o autor sobre o medo no Ocidente:

[...] quando a religião parou de assustar as pessoas, esta inventaram novos medos para se assustarem, como se valorizassem o medo como uma parte necessária da sensação de estarem vivos. [...] Desde o século VIII a segurança tornou-se, quase universalmente, a meta oficial para esta vida, mas uma meta intangível, um paraíso, sempre difícil de localizar, invisível em meio a uma nuvem de dúvidas. A Constituição americana proclamou o direito à segurança, o que significava o direito de não ter medos, mas em vão. [...] A insegurança veio a ser a queixa mais comum do nosso tempo. ${ }^{5}$.

Como se sabe, a mente é um refúgio de ideias e de mitos. ${ }^{6}$ Os medos daí consequentes funcionam como alimentadores do discurso de ódio. O medo do outro, do ser humano "diferente", e a desconfiança levam à discriminação que se expressa pelo discurso do ódio. O discurso de ódio, hate speech, foi um dos instrumentos da Guerra Fria não só no campo internacional como no interior dos países de cada bloco de poder. Na defesa de suas posições ideológicas, as pessoas se agrediam e manifestavam seu ódio à posição contrária, apelando, muitas vezes, para a violência e a delação inconsistente. Basta a lembrança do que foi o macarthismo nos Estados Unidos, nos anos 50 do século passado. O senador por Wisconsin, Joseph McCarthy (1908-1957), durante o tempo em que exerceu mandatos no Senado dos Estados Unidos, 1947 a 1957, disseminou brutal campanha de ódio no país, a pretexto de combate ao comunismo. Qualquer pessoa que se posicionava contrariamente às ideias políticas do grupo ideológico ao qual ele pertencia, era logo denunciado e processado, amiúde sob a acusação de traição. A campanha anticomunista por ele dirigida foi tão intensa que criou um substantivo - o macarthismo, palavra que o Dicionário Houaiss define como "a prática de formular acusações e fazer insinuações sem provas"? Ainda no plano internacional, entre outras situações políticas alimentadas pelo discurso de ódio, é pertinente ressaltar a violência e a intolerância, que são propagadas pelas religiões beligerantes, circunstância que fomenta o terrorismo religioso internacional. $\mathrm{O}$ uso da violência pelos movimentos terroristas islâmicos nos tempos atuais tem suas raízes históricas em muitos movimentos que, a partir de interpretações tendenciosas do Corão, elegem a violência como forma de luta para manter o político subordinado à revelação e, assim, liquidar, com ódio e violência, as

${ }^{4}$ GAY, Peter. O Cultivo do Ódio. Tradução de Sérgio de Paula e Viviane de Lamare Noronha. São Paulo: Companhia das Letras, 1995, p. 11.

${ }^{5}$ ZELDIN. Theodore. Uma História Íntima da Humanidade. Tradução de Hélio Pólvora. Rio de Janeiro: Record, 1996, p. 155156.

${ }^{6}$ A propósito, deve-se mencionar que, para Hobbes, o medo, no estado de natureza, foi o elemento que deu origem e impulsionou o contrato social do qual teria nascido o Estado.

${ }^{7}$ Charles Chaplin, por colocar-se ideologicamente à esquerda e, em alguns de seus filmes, apresentar criticas ao capitalismo, foi acusado e perseguido pelo então diretor do FBI, J. Edgar Hoover, que retirou o visto de permanência de Chaplin nos Estados Unidos, fato que o obrigou a exilar-se na Suíça. Escrevendo sobre o assunto, diz Chaplin: "Desde o fim da última guerra mundial, eu tenho sido alvo de mentiras e propagandas por poderosos grupos reacionários que, por sua influência e com a ajuda da imprensa marrom, criaram um ambiente doentio no qual indivíduos de mente liberal possam ser apontados e perseguidos. Nestas condições, acho que é praticamente impossível continuar meu trabalho do ramo do cinema e, portanto, me desfiz de minha residência nos Estados Unidos”. Esta declaração de Chaplin por ser vista em: https://pt.wikipedia.org/wiki/Charlie_Chaplin\#Era_McCarthy. Consulta em 16-07-2017. 
tendências secularistas no âmbito do Islã.

O apartheid, como regime de segregação racial adotado oficial e legalmente pelo governo de minoria branca na África do Sul, entre 1948 e 1994, constituiu-se, alimentado pelo discurso de ódio, em um dos maiores atentados perpetrados contra a condição humana. A maioria negra não tinha direitos políticos, era obrigada a viver segregada em áreas de confinamento e, conforme a Lei de Proibição dos Casamentos Mistos, aprovada por iniciativa do Partido Nacional da África do Sul, em 1949, era proibido o casamento entre pessoas de origem étnica diferente. Por outro lado, a Lei da Imoralidade, aprovada em 1950, tipificava como crime o intercurso sexual entre pessoas de raças diferentes.

O espetacular avanço nas tecnologias da informação iniciado nas últimas décadas do século passado, e que prossegue acelerado nestes primeiros tempos do Terceiro Milênio, levou o sociólogo espanhol Manuel Castells, em sua análise da sociedade informacional global, a sublinhar, com propósito, que tais conquistas transformaram "o nosso o modo de pensar, de produzir, de consumir, de negociar, de administrar, de comunicar, de viver, de morrer e de fazer a guerra. ${ }^{8}$ Creio que a tudo isso se pode aditar que tais tecnologias permitiram o aparecimento de uma um nova e feroz forma de odiar, de expressar o discurso de ódio. As campanhas políticas, por exemplo, aqui e acolá, se transformaram em exercícios virtuais de ódio. O bom marqueteiro ou consultor de Marketing Político, para usar a denominação correta, é aquele que melhor trabalha com o discurso de ódio, como vimos nas últimas eleições aqui no Brasil, nos Estados Unidos e na recente eleição na França. Argumentando com a raiva e a mentira, o discurso de ódio, semelhante a um vírus, se espalha no corpo social, fato que tira totalmente a necessária natureza democrática do pleito eleitoral, dando origem, além disso, aos estelionatos eleitorais que há várias eleições se manifestam no Brasil. Redes sociais como Facebook, Twitere Instagram, diariamente. divulgam discursos de ódio versando sobre racismo, opções político-partidárias e homofobia, mensagens expressando preconceitos e discriminação.

Em termos conceituais, pode-se dizer que o discurso de ódio é uma forma de agressividade, que sempre teve fundo ideológico e pode ser entendido como brutal manifestação de intolerância e de preconceitos de toda a ordem, contra pessoas ou grupos minoritários. O discurso de ódio esteve presente nas ações que levaram o sofrimento aos grupos sociais vítimas de genocídios, como o registrado, em Ruanda, entre 6 de Abril e 4 de Julho de 1994, no qual 800 mil pessoas foram massacradas, por motivações étnicas e políticas. Da mesma forma, foi o discurso do ódio racial e religioso que culminou na tragédia humanitária na antiga Iugoslávia. Tais catástrofes, fruto da intolerância, não podem ficar esquecidas, como também não se pode esquecer o genocídio armênio e o Holocausto. Os judeus, pelo culto de sua religião étnica, pelo fato de terem um forte sentido de vida comunitária e fidelidade às suas tradições e costumes, constituem a nação que, historicamente, mais sofreu com a discriminação

\footnotetext{
${ }^{8}$ CASTELLS, Manuel. A Era da Informação: Economia, Sociedade e Cultura. v. III. Rio de Janeiro: Paz e Terra, 1999, p. 412.
} 
de cunho religioso e cultural ao longo dos séculos. Expondo sobre a origem da palavra tolerância Vicente Barreto registra o seguinte:

A ideia de tolerância foi formulada, de forma incipiente, na teoria aristotélica a amizade, considerada como alicerce da cidade helênica (Ética a Nicômaco, livros VII e VIII). Desde então, a ideia esteve integrada à cultura política e jurídica do Ocidente, ainda que somente no início da Idade Moderna tenha adquirido o seu significado ético e político específico: atitude que consiste em admitir no outro uma maneira de pensar ou de agir diferente da adotada por si próprio. No espaço político, a tolerância consiste no fato de respeitar a liberdade do outro em matéria de opinião. [...] A palavra tolerância deriva do latim tolerantia e foi empregada pelos escritores da Antiguidade para expressar a aceitação passiva do sofrimento, da submissão e conformismo face à dor e à adversidade. Nesse sentido é que a palavra tolerance foi admitida na primeira edição do Dictionnaire de l' Academie Francaise (1684), como uma concessão, uma indulgência diante daquilo que não se pode evitar. Desde então, a ideia de tolerância teve diferentes significados, eu contribuíram para conceituá-la como virtude, por excelência, do estado democrático contemporâneo. ${ }^{9}$

É pertinente acrescentar que Voltaire, ele mesmo, um polemista satírico, perseguido e exilado na Inglaterra por suas ideias e criticas às monarquias absolutas, em seu Dicionário Filosófico, assinala, no espírito iluminista, e com sua característica radical, que "a tolerância é o apanágio da humanidade" e "todo indivíduo que persegue um homem, porque não é da sua mesma opinião, é um monstro".

\section{A QUESTÃO NO DIREITO BRASILEIRO}

O Estado liberal de direito teve no princípio da tolerância um dos seus principais elementos formuladores e, como tal, o incorporou como norma constitucional. A questão do hate speech não é consagrada de forma explicita no ordenamento constitucional brasileiro. Contudo, pode-se ver que a matéria está tratada, de forma implícita, nos vários artigos regulando matérias suscetíveis ao discurso de ódio.

A Constituição da República Federativa do Brasil de 1988 protege a liberdade de expressão nas suas mais diversas dimensões, tais como, liberdade de manifestação do pensamento, liberdade de expressão de atividade intelectual, artística, científica e de comunicação, direito à informação, de informação jornalística, dentre outras. Todavia, a Constituição da República previu também outras formas de limitá-la, como é o caso do princípio da igualdade e da não discriminação. $O$ artigo 220 da Constituição da República declara que a manifestação do pensamento, a criação, a expressão e a informação, sob qualquer forma, processo ou veículo não sofrerão qualquer restrição. Daí que a nossa Carta Maior consigna como regra, a ampla defesa e proteção do direito fundamental à liberdade de expressão, e como exceção a sua restrição. Uma das restrições à liberdade de expressão encontra-se expressa no art. $5^{\circ}$, inciso IV, que veda o anonimato. Outra restrição está prevista no artigo $220, \$ 1^{\circ}$, combinado com o artigo $5^{\circ}, \mathrm{X}, \mathrm{da} \mathrm{CRFB} / 88$ que reconhece a inviolabilidade à intimidade, à vida privada,

\footnotetext{
9 BARreto, Vicente de Paulo: Tolerância. In: Dicionário de Filosofia Política. Coordenador: Vicente de Paulo Barreto; Coordenador adjunto Alfredo Culleton. São Leopoldo RS: UNISINOS, 2010, p. 510-511.
} 
à honra e à imagem das pessoas.

O princípio da não discriminação ou da luta contra o racismo é, pois, um das restrições a liberdade de expressão. Desde o preâmbulo da nossa Constituição da República, a igualdade é posta como um valor supremo e fundamental para a existência de uma sociedade plural e aberta. Ademais, um dos objetivos fundamentais e primordiais da República do Brasil é a erradicação das desigualdades sociais e religiosas e a promoção do bem comum, sem preconceito de origem, raça, sexo, cor, idade, ou qualquer outras formas de discriminação. No caput do art. $5^{\circ}$ prescreveu o princípio da igualdade onde todos os brasileiros devem ser considerados iguais perante a lei, sem distinção de qualquer natureza, garantindo-se a todos a inviolabilidade do direito à igualdade. De forma mais específica, a Constituição em seu art. 5ㅇ, XLII, dispôs que a prática do crime de racismo deve ser inafiançável e imprescritível, nos termos da lei.

Os tribunais brasileiros já enfrentaram questões relacionadas ao hate speech. No Brasil é importante destacar o caso "Ellwanger" enfrentado no âmbito do Supremo Tribunal Federal (STF). A Corte, em setembro de 2003, por 7 votos a 3, condenou, pelo crime da prática de racismo, o editor Siegfried Ellwanger, uma vez que este, de maneira sistemática e deliberada, publicava livros notoriamente anti-semitas, como os "Protocolos dos Sábios de Sião", bem como denegava o fato histórico do Holocausto, como autor do livro "Holocausto - judeu ou alemão? Nos bastidores da mentira do século". ${ }^{10}$

\footnotetext{
10 "STF nega Habeas Corpus a editor de livros condenado por racismo contra judeus - O Supremo Tribunal Federal manteve a condenação do editor Siegfried Ellwanger imposta a ele pelo Tribunal de Justiça do Rio Grande do Sul por crime de racismo. O julgamento do Habeas Corpus (HC 82424) ajuizado pela defesa de Ellwanger foi concluído hoje (17/9). Por maioria de sete a três, o Plenário negou o recurso, vencidos os ministros Moreira Alves, Marco Aurélio e Carlos Ayres Britto. Os dois primeiros consideraram o crime prescrito. Ayres Britto concedia o recurso de ofício para absolver o livreiro por falta de provas. A discussão foi retomada com o voto-vista do ministro Marco Aurélio. Ele concedeu o Habeas Corpus ao julgar que o editor gaúcho não cometeu crime de racismo. Considerou, também, que sua punição estaria prescrita acompanhando, nesse ponto, o voto do relator, ministro Moreira Alves. Em quase 72 laudas e meia, o ministro Marco Aurélio defendeu o direito à liberdade de expressão, definindo o julgamento como um dos mais importantes do STF, desde que chegou ao Tribunal, há 13 anos. Marco Aurélio justificou ponto de vista de proteção à manifestação individual de pensamento, por entender que o livreiro quis fazer uma revisão histórica. De acordo com o ministro, a Constituição Federal não se referiu ao povo judeu, mas ao preconceito contra os negros, ao tratar da prática do crime de racismo, que considera imprescritivel, no inciso XLII, artigo $5^{\circ}$. Isto porque, segundo Marco Aurélio, a Constituição de 1988 se aplica ao povo brasileiro. O ministro também considerou que a não prescrição de crimes iria contra a garantia constitucional dos direitos fundamentais. "O instituto da imprescritibilidade de crime conflita com a corrente das garantias fundamentais do cidadão, pois o torna refém, eternamente, de atos ou manifestações - como se não fosse possível e desejável a evolução, a mudança de opiniōes e de atitudes, alijando-se a esperança, essa força motriz da humanidade -, gerando um ambiente de total insegurança jurídica, porquanto permite ao Estado condená-lo décadas e décadas após a prática do ato", apontou. Marco Aurélio rememorou voto do colega Carlos Ayres Britto; historiou sobre censura e liberdade de expressão; falou sobre tolerância; distinguiu entre preconceito e discriminação e defendeu o ponto de vista de que o livreiro quis fazer uma revisão histórica. Sua defesa da liberdade individual de manifestação do pensamento foi reiterada em todo o voto. "Há de se proclamar a autonomia do pensamento individual como uma forma de proteção à tirania imposta pela necessidade de adotar-se sempre o pensamento politicamente correto. As pessoas simplesmente não são obrigadas a pensar da mesma maneira", defendeu ele. "Por exemplo, estaria configurado o crime de racismo se o paciente, em vez de publicar um livro no qual expostas suas idéias acerca da relação entre os judeus e os alemães na Segunda Guerra Mundial, como na espécie, distribuísse panfletos nas ruas de Porto Alegre com dizeres do tipo "morte aos judeus", "vamos expulsar estes judeus do País", "peguem as armas e vamos exterminá-los". Mas nada disso aconteceu no caso em julgamento. O paciente restringiu-se a escrever e a difundir a versão da história vista com os próprios olhos", disse adiante.
} 
"A questão de fundo neste habeas corpus diz respeito à possibilidade de publicação de livro cujo conteúdo revele idéias preconceituosas e anti-semitas. Em outras palavras, a pergunta a ser feita é a seguinte: o paciente, por meio do livro, instigou ou incitou a prática do racismo? Existem dados concretos que demonstrem, com segurança, esse alcance? A resposta, para mim, é desenganadamente negativa", justificou. Em seguida, os ministros Celso de Mello, Carlos Velloso e Gilmar Mendes, Nelson Jobim e Ayres Britto ratificaram votos já proferidos sobre a matéria e, à exceção de Britto, indeferiram o pedido feito pela defesa do livreiro. Último a concluir voto, já no inicio da noite, o ministro Sepúlveda Pertence acompanhou a corrente majoritária que negou o Habeas Corpus, "A discussão me convenceu de que o livro pode ser instrumento da práatica de racismo. Eu não posso entender isso como tentativa subjetivamente séria de revisão histórica de coisa nenhuma", votou ele. HISTÓRICO: O julgamento do pedido de Habeas Corpus (HC 82424) de Sigfried Ellwanger, iniciado em dezembro do ano passado, levou nove meses para ser concluído. O pedido, no entanto, foi negado em junho, quando a maioria dos ministros entendeu que a prática de racismo abrange a discriminação contra os judeus. Após o voto do ministro Moreira Alves, em 12 de dezembro de 2002, um pedido de vista do ministro Maurício Corrêa suspendeu o julgamento por divergir do relator. Moreira Alves defendeu a tese de que os judeus não podem ser considerados como "raça" e Maurício Corrêa questionou "a interpretação semântica". Em abril deste ano, o recurso voltou ao Plenário. Maurício Corrêa disse que a genética baniu o conceito tradicional de raça e que a divisão dos seres humanos em raças decorre de um processo político-social, originado da intolerância dos homens. Foi a vez do ministro Gilmar Mendes pedir vista. Na mesma sessão, no entanto, o ministro Celso de Mello preferiu antecipar seu voto, no mesmo sentido das razões defendidas pelo ministro Maurício Corrêa. Em junho, o Habeas Corpus voltou a julgamento com o Plenário completo, já com a presença dos novos ministros Carlos Ayres Britto, Cezar Peluso e Joaquim Barbosa. Dos três, o ministro Joaquim Barbosa foi o único a não votar por ter assumido a vaga do relator do pedido, Moreira Alves. Na sessão de 26 de junho deste ano, após o voto do ministro Antônio Peluso houve o pedido de vista do ministro Carlos Ayres Britto. Nesta mesma sessão, votaram os ministros Gilmar Mendes, Carlos Velloso, Nelson Jobim, e Ellen Gracie. A votação já havia atingido a maioria com o indeferimento do pedido, por 7 votos a 1. O ministro Marco Aurélio, no entanto, pediu vista do recurso. O Habeas Corpus finalmente voltou hoje (17/9) ao Plenário com os votos dos ministros Marco Aurélio e Sepúlveda Pertence. Após a concessão do recurso pelo ministro Marco Aurélio, os ministros Celso de Mello, Carlos Velloso, Gilmar Mendes, Nelson Jobim e Cezar Peluso reiteraram seus votos. O ministro Sepúlveda Pertence encerrou o julgamento. Vejamos como votaram os Ministros: Voto do Ministro Moreira Alves - O ministro Moreira Alves entendeu que "os judeus não podem ser considerados uma raça", por isso, não se poderia qualificar o crime por discriminação, pelo qual foi condenado Siegfried Ellwanger, como delito de racismo. O relator concedia o Habeas Corpus, declarando extinta a punibilidade do acusado, pois já teria ocorrido a prescrição do crime. Corrêa divergiu do relator, ao negar o Habeas Corpus sob o argumento de que a genética baniu de vez o conceito tradicional de raça e que a divisão dos seres humanos em raças decorre de um processo político-social originado da intolerância dos homens. Para Maurício Corrêa, a Constituição coíbe atos desse tipo, "mesmo porque as teorias anti-semitas propagadas nos livros editados pelo acusado disseminam idéias que, se executadas, constituirão risco para a pacífica convivência dos judeus no país”. Voto do Ministro Celso de Mello - O ministro acompanhou a dissidência, afirmando que "só existe uma raça: a espécie humana". E frisou: "Aquele que ofende a dignidade de qualquer ser humano, especialmente quando movido por razões de cunho racista, ofende a dignidade de todos e de cada um". Achou correta a condenação de Ellwanger, negando-lhe o Habeas Corpus. Voto do Ministro Gilmar Mendes - Gilmar Mendes também negou a ordem de Habeas Corpus, por entender que "o racismo configura conceito histórico e cultural assente em referências supostamente raciais, aqui incluído o anti-semitismo". Para Mendes, "não se pode atribuir primazia à liberdade de expressão, no contexto de uma sociedade pluralista, em face de valores outros como os da igualdade e da dignidade humana”. Por isso o texto constitucional erigiu o racismo como crime inafiançável e imprescritível. Voto do Ministro Carlos Velloso - Carlos Velloso também indeferiu o Habeas Corpus, por acreditar que o anti-semitismo é uma forma de racismo. Segundo o ministro, nos livros publicados por Ellwanger, os judeus são percebidos como raça, porque há pontos em que se fala em "inclinação racial e parasitária dos judeus", o que configuraria uma conduta racista, vedada pela Constituição Federal. Voto do Ministro Nelson Jobim - O ministro Nelson Jobim julgou que Ellwanger não editou os livros por motivos históricos, mas como instrumentos para produzir o anti-semitismo. Para ele, esse é um "caso típico" de fomentação do racismo, por isso acompanhou a ala dissidente, negando o Habeas Corpus. Voto do Ministra Ellen Gracie - Em seu voto, a ministra Ellen Gracie trouxe a definição de raça presente na Enciclopédia Judaica, na qual "a concepção de que a humanidade está dividida em raças diferentes encontra-se de maneira vaga e imprecisa na Bíblia, onde, no entanto, como já acentuavam os rabinos, a unidade essencial de todas as raças é sugerida na narrativa da criação e da origem comum de todos os homens". Nessa linha, negou a ordem. Voto do Ministro Cezar Peluso - Peluso seguiu a maioria e votou pela denegação do Habeas Corpus. "A discriminação é uma perversão moral, que põe em risco os fundamentos de uma sociedade livre”, disse. Voto do Ministro Carlos Ayres Britto - Carlos Ayres Britto concedia o Habeas Corpus de ofício - por iniciativa do próprio Supremo - pois entendeu não haver justa causa para instauração de ação penal contra Ellwanger. Em seu voto, Britto absolvia, então, o réu, por atipicidade do crime, porque a lei que tipificou o crime de racismo por meio de comunicação foi promulgada depois de Ellwanger ter cometido o delito. Voto do Ministro Marco Aurélio - O ministro Marco Aurélio também concedia o Habeas Corpus, defendendo a tese da liberdade de expressão. "A questão de fundo neste Habeas Corpus diz respeito à 
Outro caso, no Brasil, bem conhecido é aquele que ficou nominado de "Marcha da Maconha". "Em decisão unânime ( 8 votos), o Supremo Tribunal Federal (STF) liberou a realização dos eventos chamados "marcha da maconha", que reúnem manifestantes favoráveis à descriminalização da droga. Para os ministros, os direitos constitucionais de reunião e de livre expressão do pensamento garantem a realização dessas marchas. Muitos ressaltaram que a liberdade de expressão e de manifestação somente pode ser proibida quando for dirigida a incitar ou provocar ações ilegais e iminentes.

Pela decisão, tomada no julgamento de ação (ADPF 187) ajuizada pela Procuradoria-Geral da República (PGR), o artigo 287 do Código Penal deve ser interpretado conforme a Constituição de forma a não impedir manifestações públicas em defesa da legalização de drogas. O dispositivo tipifica como crime fazer apologia de "fato criminoso" ou de "autor do crime".

O voto do decano da Corte, ministro Celso de Mello, foi seguido integralmente pelos colegas. Segundo ele, a "marcha da maconha” é um movimento social espontâneo que reivindica, por meio da livre manifestação do pensamento, "a possibilidade da discussão democrática do modelo proibicionista (do consumo de drogas) e dos efeitos que (esse modelo) produziu em termos de incremento da violência”.

Além disso, o ministro considerou que o evento possui caráter nitidamente cultural, já que nele são realizadas atividades musicais, teatrais e performáticas, e cria espaço para o debate do tema por meio de palestras, seminários e exibições de documentários relacionados às políticas públicas ligadas às drogas, sejam elas lícitas ou ilícitas.

Celso de Mello explicou que a mera proposta de descriminalização de determinado ilícito penal não se confunde com o ato de incitação à prática do delito nem com o de apologia de fato criminoso. "O debate sobre abolição penal de determinadas condutas puníveis pode ser realizado de forma racional, com respeito entre interlocutores, ainda que a ideia, para a maioria, possa ser eventualmente considerada estranha, extravagante, inaceitável ou perigosa", ponderou.

Mesmo acompanhando o relator, o ministro Luiz Fux achou necessário estabelecer parâmetros para a realização das manifestações. Fux ressaltou que elas devem ser pacíficas, sem uso de armas e incitação à violência.

possibilidade de publicação de livro cujo conteúdo revele idéias preconceituosas e anti-semitas. Em outras palavras, a pergunta a ser feita é a seguinte: o paciente, por meio do livro, instigou ou incitou a prática do racismo? Existem dados concretos que demonstrem, com segurança, esse alcance? A resposta, para mim, é desenganadamente negativa”. Em sua opinião, somente estaria configurado o crime de racismo se Ellwanger, em vez de publicar um livro "no qual expõe suas idéias acerca da relação entre os judeus e os alemães na Segunda Guerra Mundial, como na espécie, distribuísse panfletos nas ruas de Porto Alegre com dizeres do tipo 'morte aos judeus', 'vamos expulsar estes judeus do País', 'peguem as armas e vamos exterminá-los'. Mas nada disso aconteceu no caso em julgamento". Segundo Marco Aurélio, Ellwanger restringiu-se a escrever e a difundir a versão da história vista com os próprios olhos. Voto do Ministro Sepúlveda Pertence - Sepúlveda Pertence optou por negar o Habeas Corpus ao editor gaúcho. Para o ministro, "a discussão me convenceu de que o livro pode ser instrumento da prática de racismo. Eu não posso entender isso como tentativa subjetivamente séria de revisão histórica de coisa nenhuma”, votou." Disponível em: <http://www.stf.jus.br/portal/cms/verNoticiaDetalhe.asp?idConteudo=61291.>. Acesso em: 08 jul 2014. 
Também devem ser previamente noticiadas às autoridades públicas, inclusive com informações como data, horário, local e objetivo do evento.

Ele acrescentou ser "imperioso que não haja incitação, incentivo ou estímulo ao consumo de entorpecentes" durante a marcha e deixou expresso que não pode haver consumo de entorpecentes no evento.

Por fim, ressaltou que crianças e adolescentes não podem ser engajados nessas marchas. "Se a Constituição cuidou de prever a proteção dos menores dependentes químicos, é corolário dessa previsão que se vislumbre um propósito constitucional de evitar tanto quanto possível o contato das crianças e dos adolescentes com a droga e com o risco eventual de uma dependência”, afirmou.

Nesse ponto, o ministro Celso de Mello observou que o dispositivo legal que estabelece o dever dos pais em relação a seus filhos menores é uma regra que se impõe por si mesma, por sua própria autoridade. Ele acrescentou que demais restrições impostas a eventos como a "marcha da maconha" estão determinados na própria Constituição.

A ministra Cármen Lúcia Antunes Rocha acompanhou o voto do relator citando a seguinte afirmação de um jurista americano: "Se, em nome da segurança, abrirmos mão da liberdade, amanhã não teremos nem liberdade nem segurança”. Ela manifestou simpatia por manifestações de rua e lembrou que, há 30 anos, sua geração era impedida de se expressar pela mudança de governo na Praça Afonso Arinos, contígua à Faculdade de Direito, em Belo Horizonte (MG), onde a ministra se formou.

Segundo Cármen Lúcia, é necessário assegurar o direito de manifestação sobre a criminalização ou não do uso da maconha, pois manifestações como essas podem conduzir a modificações de leis." ${ }^{11}$

Mais recentemente, ainda no Brasil, a problemática envolvendo a liberdade de expressão e o discurso de ódio, surgiu no Rio de Janeiro. Integrantes da Umbanda e do Candomblé protestam em Brasília contra decisão judicial que negou pedido de retirada de vídeos com mensagem de intolerância religiosa do YouTube. Vejamos: "Religiosos/as do Candomblé e da Umbanda ocupam Brasília hoje para exigir respeito e tratamento digno às religiões de matriz africana. Vindos de várias regiões do País, o grupo denuncia a sistemática violação do direito de crença e liberdade das minorias religiosas. A mobilização foi motivada pelo repúdio à decisão do juiz titular da 17.a Vara Federal do Rio de Janeiro, Eugênio Rosa de Araújo, que negou o pedido de retirada de vídeos do YouTube com mensagens de intolerância contra religiões afro-brasileiras. Um dos vários episódios recentes trouxe à tona a discussão sobre o direito à liberdade de expressão. Ao negar pedido do Ministério Público Federal (MPF) para que fossem excluídos vídeos que ostensivamente atacavam as religiões de matriz africana e ofendiam seus praticantes, o juiz usou como argumento o direito à liberdade de expressão: "Tendo sido afirmado que tais vídeos são de mau gosto, como ficou expressamente assentado na decisão recorrida, porém refletem exercício regular da

\footnotetext{
${ }^{11}$ Disponível em: <http://www.stf.jus.br/portal/cms/verNoticiaDetalhe.asp?idConteudo=182124.> Acesso em: 08 jul 2014.
} 
referida liberdade [de expressão]", afirmou o texto da decisão publicado em 28 de abril. [....." 12

Outro caso concreto no Brasil é aquele que ficou conhecido como "caso Rachel Sheherazade". A jornalista Rachel Sheherazade entoou um discurso polêmico e raivoso defendendo os "vingadores" que espancaram e amarram um jovem a um poste no Rio de Janeiro. Daí que "a Procuradoria Geral da República (PGR) aceitou nesta quinta-feira (27) a representação feita pela deputada federal Jandira Feghali (PCdoB/RJ) contra a jornalista Rachel Sheherazade, do SBT. A parlamentar solicita uma investigação, alegando que a âncora do "SBT Brasil" cometeu na bancada do telejornal o crime de apologia e incitamento à tortura e ao linchamento, caracterizado no artigo 287 do Código Penal.

De acordo com o procurador-geral da República, Rodrigo Janot, os vídeos que mostram a opinião exposta por Rachel no "SBT Brasil" sobre o caso envolvendo um grupo que puniu um menor infrator no Rio de Janeiro serão avaliados. "Não se pode pregar contra o Estado democrático. Isso é muito sério" , opina Janot. "Se você faz um discurso de ódio para a sociedade, não há como controlar o que ocorre depois por aí", completa.

Em nota enviada ao Purepeople, Jandira Feghali explica que seu pedido de investigação se justifica. "As pessoas não podem se sentir legitimadas por um discurso neofascista e sair por aí julgando e executando outros cidadãos. E, no geral, os executados em sua maioria são os mais pobres e negros" , diz. "Não queremos que se crie um paradigma na televisão de incitação à violência na busca da audiência e do lucro. É preciso repensar o que está sendo feito", critica.

\section{Polêmica}

Em fevereiro deste ano, um adolescente foi espancado e preso nu pelo pescoço a um poste através uma trava de bicicleta por homens no Aterro do Flamengo, na Zona Sul da capital fluminense. O jovem cometia furtos na região. Com a notícia, Rachel Sheherazade, que ficou conhecida por causa de suas opiniões fortes, deu o seu parecer sobre o fato no "SBT Brasil".

"No país que ostenta incríveis 26 assassinatos a cada 100 mil habitantes, que arquiva mais de 80\% de inquéritos de homicídio e sofre de violência endêmica, a atitude dos vingadores é até compreensível. O Estado é omisso, a polícia é desmoralizada, a Justiça é falha. O que resta ao cidadão de bem que, ainda por cima, foi desarmado? Se defender, é claro", disse.

"O contra-ataque aos bandidos é o que chamo de legítima defesa coletiva de uma sociedade sem Estado contra um estado de violência sem limite. E, aos defensores dos Direitos Humanos, que se apiedaram do

12 MIELKI, Ana Cláudia. Liberdade de expressão ou discurso de ódio? Disponível em: < http://www.cartacapital.com.br/blogs/intervozes/liberdade-de-expressao-ou-discurso-de-odio-2280.html>. Acesso em: 22 jun 2014 . 
marginalzinho preso ao poste, eu lanço uma campanha: faça um favor ao Brasil, adote um bandido", encerrou Rachel." ${ }^{13}$

\section{O PROBLEMA NOS ESTADOS UNIDOS DA AMÉRICA}

Como é notório, desde os tempos iniciais da formação dos Estados Unidos como Estado independente, principalmente após a Guerra de Secessão, o discurso do ódio, de fundo racial, sobretudo, contra os negros, em sido uma constante na história do país. O movimento terrorista Ku Klux Kan, criada no Tennessee, em 1866, originalmente como clube de veteranos confederados para lutar pela supremacia branca por meio da intimidação e da violência contra negros recém-libertados, ao encerar suas atividade em 1890, esta primeira Ku Klux Kan era apontada nos Estados Unidos como uma das organizações secretas mais ferozes e odiadas do país. ${ }^{14}$ No início do século XX foi criada outra Ku Klux Kan, em Atlanta, na Geórgia que atuava na mesma linha terrorista e de permanente violação dos direitos humanos. Tolerada e protegida pelas autoridades dos Estados do Sul dos Estados Unidos - muitos de seus membros eram funcionários do aparato policial -, suas células espalhavam o terror, sempre à noite, com seus militantes mascarados e portando uma cruz. Inicialmente agia apenas contra negros, mas, por volta dos anos vinte, quando contava com mais de quatro milhões de membros, principalmente nas localidades do Sul, passou também a perseguir, torturar e matar judeus, mexicanos, latinos, homossexuais e membros de organizações sindicais. Hoje, embora não extinta, não funciona mais como sociedade secreta. Segundo as entidades de defesa dos direitos civis nos Estados Unidos, ela é responsável por mais 1.500 mortes por linchamento. Há registros de ataques terroristas da Ku Klux Kan até 1980.

Nos Estados Unidos o discurso de ódio é visto como um problema político. Até que ponto a liberdade de expressão se coaduna ou não com os discursos de ódio? Esta é uma questão tormentosa nos Estados Unidos, já que a partir de uma dimensão igualitária existe uma tendência constitucional política a proteger o conteúdo do discurso, independentemente de seu mérito. A igualdade política passa a ser questionada a partir do momento que grupos racistas e segregacionistas manifestam seus discursos ancorados na liberdade de expressão. A questão é polêmica uma vez que "reprimir a expressão desses grupos seria amputar o leque político de uma de suas alas, impedindo-lhes o acesso de parcela do espectro ideológico à esfera pública deliberativa. Por outro lado, dar livre curso ao preconceito pode causar sérios danos a integrantes de grupos étnicos e sociais minoritários." ${ }^{15}$

\footnotetext{
${ }^{13}$ Disponível em: <http://www.pbagora.com.br/conteudo.php?id=20140331085158\&cat=politica\&keys=-apos-denuncia-aceitapela-pgr-rachel-sheherazade-entra-ferias-sbt.> Acesso em: 22 jun 2014.

${ }^{14}$ Em certa fase de sua atuação, o poder da Ku Klux Kan era de tal ordem que acabou por influenciar a formação de outros grupos semelhantes, como as organizações terroristas "Camélia Branca”, "Liga Branca”, "Círculo Invisível” e "Rostos Pálidos", todas com a finalidade de linchar e matar negros.

${ }^{15}$ SILVA, Júlio César Casarin Barroso. Democracia e Liberdade de Expressão: Contribuições para uma Interpretação Política da Liberdade da Palavra. Tese de Doutorado. São Paulo: USP, 2009, p.140.
} 
A seguir, com o propósito de ilustrar a polêmica acima mencionada, vale destacar os casos concretos apontados por Júlio César Casarin Barroso Silva, em sua tese de doutorado apresentada à Faculdade de Filosofia, Letras e Ciências Humanas, do Departamento de Ciência Política da USP. Vejamos:

1. "Um caso importante foi Beauharnais v. Illinois. Uma lei estadual de Illinois criminalizava a publicação ou exibição de publicação que retratasse "depravação, criminalidade, lubricidade ou falta de virtude de uma classe de cidadãos, de qualquer raça, cor, credo ou religião" ou que expusesse "qualquer raça, credo ou religião a desprezo, escárnio, vilipêndio" e que por isso fosse capaz de produzir a "quebra de paz ou distúrbios". Joseph Beauharnais foi condenado por ter feito uma mobilização e recolhido assinaturas instando as autoridades públicas municipais de Chicago a impedir "a invasão de bairros brancos pelos 'crioulos"' e a impedir a "mistura" destes - associados no panfleto a "agressões, estupros, roubos, facas, armas de fogo e maconha" - com a raça branca [sic]. Frankfurter, falando pela Corte numa decisão tomada por estreita maioria de 5 a 4, apoiou a lei de Illinois. Não o fez, contudo, não em nome de alguma concepção de igualdade ou com o intuito de proteger as categorias raciais atacadas. As razões apresentadas para justificar a decisão foram baseadas na exclusão histórica de difamação (libel) do que se entendia por liberdade de expressão, na necessidade de deferência judicial ao Poder Legislativo em que se tratando de matéria controversa e complexa e, fundamentalmente, nos riscos que expressões de ódio poderiam trazer à coesão e à harmonia social." 1617

2. Caso Skokie. "É o caso de Skokie, cidadezinha próxima a Chicago que na época que os eventos ocorreram, na segunda metade da década de 1979, tinha uma parcela considerável de população judia, inclusive um número significativo de sobreviventes do Holocausto. Foi aí que, provocativamente, o Partido Nazista dos Estados Unidos decidiu fazer uma manifestação, marchando pela cidade portando suas suásticas e outros símbolos de ódio. Apesar dos esforços jurídicos e políticos das autoridades locais

\footnotetext{
${ }^{16}$ Ibid., p.141.

${ }^{17}$ U.S. Supreme Court

Beauharnais v. Illinois, 343 U.S. 250 (1952)

Beauharnais v. Illinois

No. 118

Argued November 28, 1951

Decided April 28, 1952

343 U.S. 250

CERTIORARI TO THE SUPREME COURT OFILLINOIS

Syllabus
}

Over his claim that the statute violated the liberty of speech and of the press guaranteed as against the States by the Due Process Clause of the Fourteenth Amendment and was void for vagueness, petitioner was convicted in a state court for distributing on the streets of Chicago anti-Negro leaflets in violation of Ill.Rev.Stat., 1949, c. 38, \$ 471, which makes it a crime to exhibit in any public place any publication which "portrays depravity, criminality, unchastity, or lack of virtue of a class of citizens, of any race, color, creed or religion" which "exposes the citizens of any race, color, creed or religion to contempt, derision, or obloquy." Disponível em: < https://supreme.justia.com/cases/federal/us/343/250/case.html>. Acesso em 22 jun 2014. 
para impedir semelhante manifestação, o Partido Nazista acabou recebendo a permissão do Sétimo Circuito da Justiça Federal estadunidense para realizá-la. A marcha acabou não se realizando por decisão dos neonazistas, que, ao que parece, contentaram-se apenas com o reconhecimento de que tinham o direito de realizá-la. Mas poderia ter sido realizado, e o que nos interessa aqui é o fato de que o judiciário a autorizou com base na liberdade de expressão." ${ }^{18}$

3. Caso R.A.V. v. City of Saint Paul. "Robert A. Viktora, um adolescente branco, foi condenado por ter queimado, junto com amigos, uma cruz de madeira no quintal de uma família negra. Como se sabe, a queima de cruzes é uma forma de manifestação política de grupos racistas, defensores da "supremacia branca" e da segregação racial nos EE. UU., sendo frequentemente associada ao grupo Ku Klux Klan. Mas ao mesmo tempo em que traduz uma manifestação política, racista e abjeta, no nosso entender, mas uma manifestação política, enfim, a queima de cruzes é muitas vezes usada como "advertência", ou, fazendo as pazes com o léxico e chamando as coisas pelo nome que elas têm, como ameaça a negros e a membros de outras minorias que desafiam as regras de separação racial defendidas pela KKK.

Não sabemos se a ação se resumiu a uma brincadeira de mau gosto dos adolescentes desocupados ou se se tratava de fato de uma ameaça á família negra. Mas as circunstâncias do caso concreto interessam-nos menos aqui do que a decisão da Corte e a moralidade política que a sustenta. $\mathrm{O}$ fato é que os adolescentes foram presos e julgados por violação de uma lei local de 1989 que criminalizava a exibição de cruzes ardentes, suásticas e quaisquer símbolos capazes de produzir, "raiva, alarme, ressentimento em outros com base na raça, cor, credo, religião ou gênero."'." 19

\section{O DISCURSO DE ÓDIO E A JURISPRUDENCIA DA CORTE INTERAMERICANA DE DIREITOS HUMANOS}

A aprovação pelas Nações Unidas da Carta Internacional dos Direitos Humanos, compreendendo a Declaração Universal dos Direitos do Homem, o Pacto de Direitos Econômicos, Sociais e Culturais e o Pacto de Direitos Civis e Políticos, e seus Protocolos Facultativos ${ }^{20}$, no século passado, foi o ponto de partida de uma rica fase legislativa, sob os auspícios das Nações Unidas, que redundou na aprovação de uma série de resoluções,

\footnotetext{
${ }^{18}$ SILVA, Júlio César Casarin Barroso. Democracia e Liberdade de Expressão: Contribuições para uma Interpretação Política da Liberdade da Palavra. Tese de Doutorado. São Paulo: USP, 2009, p.142.

${ }^{19}$ Ibid., p.143.

${ }^{20}$ O Pacto Internacional sobre os Direitos Econômicos, Sociais e Culturais, aprovado pela Resolução 2200 A (XXI) de 16 de Dezembro de 1966 da Assembleia Geral, entrou em vigor em 3 de Janeiro de 1976. O Pacto Internacional sobre os Direitos Civis e Políticos, aprovado pela mesma Resolução 2200 A (XXI), entrou em vigor a 23 de Março de 1976. O primeiro Protocolo facultativo referente ao Pacto Internacional sobre os Direitos Civis e Políticos entrou em vigor simultaneamente ao Pacto. O segundo Protocolo facultativo ao Pacto de Direitos Civis e Políticos foi aprovado pela Resolução 44/128 da Assembleia Geral, entrou em vigor em 5 de dezembro de 1991.
} 
declarações e de convenções multilaterais que formaram um substancial corpus juris que se destina à proteção dos direitos humanos, No âmbito desta normativa pode-se apontar para o Pacto Internacional para a Eliminação de Todas as Formas de Discriminação Racial, cujo artigo $4^{\circ}$ se posiciona de forma objetiva contra atitudes e ações que possam expressar qualquer forma de discurso de ódio. O referido artigo dispõe que os Estados Partes condenem e declarem puníveis por lei, toda propaganda e todas as organizações que se inspirem em ideias ou teorias baseadas na superioridade de uma raça ou de um grupo de pessoas de uma certa cor ou de uma certa origem étnica ou que pretendem justificar ou encorajar qualquer forma de ódio e de discriminação racial. O Pacto Internacional de Direitos Civis e Políticos estipula em seu artigo 19 que todo ser humano tem direito à liberdade de expressão, contudo, dispõe também que tal direito está sujeito a certas restrições estabelecidas em lei.

No sistema interamericano de proteção dos direitos humanos, a Corte Interamericana de Direitos Humanos firmou jurisprudência em vários casos que lhe foram submetidos sob a alegada violação, entre outros, dos artigos 13.1 e 13.3 da Convenção Americana sobre Direitos Humanos, que consagram o direito à liberdade de expressão. ${ }^{21} \mathrm{O}$ primeiro Caso julgado pela Corte foi resolvido pela sentença exarada no Caso $A$ Última Tentação de Cristo (Olmedo Bustos e Outros Vs. Chile. (Em 5 de fevereiro de 2001). Em suas sentenças e, da mesma forma, em suas opiniões consultivas, a Corte Interamericana de Direitos Humanos tem reafirmado a obrigação dos Estados de dotarem suas legislações internas dos dispositivos legais para tornar efetivos seus compromissos internacionais em matéria de direitos humanos. Nessa matéria é importante destacar a sentença no Caso em questão. A Corte, recebendo da Comissão Interamericana de Direitos Humanos a denúncia de violação do direito de liberdade de pensamento e de expressão, condenou o Estado chileno pela violação do artigo 13 da Convenção Americana. Em sua decisão, concluiu, que o Chile deixou de cumprir, no caso, os deveres gerais do artigo 1.1 e 2 da Convenção Americana sobre Direitos Humanos em conexão com a violação do direito à liberdade de pensamento e de expressão. Em razão disso, a Corte decidiu que o Estado chileno devia modificar seu ordenamento interno, num prazo razoável (o que foi feito) com o fim de suprimir a censura prévia à exibição do filme a Última Tentação de Cristo, uma vez que o artigo 19, n 12, da Constituição do Chile, em vigor, estabelecia um sistema de censura para a exibição e publicidade da produção cinematográfica. Em seu Voto Concordante, o então Juiz Presidente da Corte Interamericana de Direitos Humanos, Antônio Augusto Cançado Trindade declarou o seguinte:

O caso "A Última Tentação de Cristo", que a Corte Interamericana acaba de decidir na presente Sentença sobre o mérito, é verdadeiramente emblemático, não apenas por constituir o primeiro caso sobre liberdade de pensamento e de expressão decidido pela Corte, em sua primeira sessão de trabalho realizada no século XXI, como também - e, sobretudo - por incidir sobre uma questão comum a tantos países latino-americanos e

\footnotetext{
${ }^{21}$ A Ultima Tentação de Cristo - Olmedo Bustos e outros vs. Chile; Ivcher Bronstein vs. Peru; Ricardo CAnese vs. Paraguai; Claude Reyes e eoutros vs Chile; Kimel vs. Argentina; Tristá Donoso vs. Panamá; Rios e outros vs. Venezuela; e Tontevecchia e D"Amico vs. Argentina.
} 
caribenhos, e que alcança os fundamentos do direito da responsabilidade internacional do Estado e da própria origem desta responsabilidade. ${ }^{22}$

Ainda em relação à jurisprudência da Corte Interamericana de Direitos Humanos, deve-se observar o disposto no seu Parecer Consultivo OC7/86, de 29 de agosto de 1986, emitido à solicitação do governo da Costa Rica, sobre a Exigibilidade do Direito de Retificação ou Resposta (artigos 14.1, 1.1 e 2 da Convenção Americana sobre Direitos Humanos). Nessa matéria a Corte esclareceu que "o direito de retificação ou resposta é um direito ao qual são aplicáveis as obrigações dos Estados Partes consagradas nos artigos 1.1 e 2 da Convenção. E não poderia ser de outra forma, já que o próprio sistema da Convenção está dirigido a reconhecer direitos e liberdades às pessoas e não a facultar os Estados a fazê-lo”. (Parágrafo 24). Portanto, conforme o artigo 14. 1 da Convenção Americana sobre Direitos Humanos, "qualquer pessoa que se sentir ofendida por informações inexatas, emitidas em seu prejuízo por meios de difusão legalmente regulamentado e que se dirijam ao publico em geral, tem o direito de fazer, pelo mesmo órgão de difusão, sua retificação ou resposta, nas condições que estabeleça a lei. 2 . Em nenhum caso a retificação ou a resposta eximirão das outras responsabilidades legais em que se houver incorrido. 3. Para a efetiva proteção da honra e da reputação, toda publicação ou empresa jornalística, cinematográfica, de rádio ou televisão, deve ter uma pessoa responsável que não seja protegida por imunidades nem goze de foro especial". No parágrafo 25, ao tratar da correlação entre os direitos de expressão e de resposta a ofensas publicadas em veículos de informação, a Corte assevera que a "localização do direito de retificação ou resposta (artigo 14) imediatamente depois da liberdade de pensamento e de expressão (artigo 13) confirma esta interpretação. A necessária relação entre o conteúdo destes artigos decorre da natureza dos direitos que reconhecem, já que, ao regulamentar a aplicação do direito de retificação ou resposta, os Estados Partes devem respeitar o direito de liberdade de expressão que garante o artigo 13 e este último não pode ser interpretado de maneira tão ampla que torne nulo o direito proclamado pelo artigo 14.1”.

O artigo 14.1 não indica se os afetados têm direito a responder em espaço igual ou maior, quando se deve publicar a resposta uma vez recebida, em que período se pode exercer o direito, que terminologia é admissível, etc. De acordo com o mesmo artigo estas condições serão as "que estabeleça a lei", frase que implica uma linguagem que, à diferença da utilizada em outros artigos da Convenção ("estará protegido pela lei", "em conformidade com a lei", "expressamente fixadas por lei", etc.), requer o estabelecimento das condições para o exercício do direito de retificação ou resposta por meio da "lei", cujo conteúdo poderá variar de um Estado a outro, dentro de certos limites razoáveis e no âmbito dos conceitos afirmados pela Corte.

\footnotetext{
${ }^{22}$ Corte Interamericana de Direitos Humanos. Caso A Última Tentação de Cristo (Olmedo Bustos e Outros Vs. Chile. Sentença, (Mérito, Reparações e Custas) de 5 de fevereiro de 2001. Voto Concordante do Juiz Antônio Augusto Cançado Trindade, parágrafo 40., p. 13. O teor completo da Sentença por ser consultado em: http://www.cnj.jus.br/files/conteudo/arquivo/2016/04/f30eb7942e6ea89e4d2ec4ca870784d3.pdf Consulta em 16 de julho de 2017.
} 


\section{CONSIDERAÇÕES FINAIS}

O discurso do ódio é caracterizado pelo uso da linguagem como forma de atingir determinados grupos, especialmente aqueles historicamente vitimizados. É, pois, necessário realizar uma hermenêutica constitucional com vistas a verificar se o ato discursivo está em sintonia com o princípio da liberdade de expressão ou se a dimensão da linguagem utilizada constitui um discurso ofensivo. Dessa maneira, os discursos que desqualificam os grupos minoritários não podem ser aceitos ou tolerados em uma sociedade democrática.

A compreensão é um existencial e o exegeta deve se inserir na circularidade hermenêutica, através da précompreensão, de forma a compreender a existência ou não do discurso do ódio através da linguagem. Assim, é necessário a compreensão do fenômeno jurídico no sentido peculiar de sua problemática e de sua relação com o mundo da vida (mundo vivido). Melhor dizendo: a compreensão do discurso do ódio deve ser analisada através de uma leitura, necessariamente, histórica e temporal, levando em consideração a realidade, a tradição e a linguagem.

Na sociedade contemporânea, urge por em prática, no Estado Democrático de Direito, todos os elementos da ordem político-jurídica destinados à promoção da inclusão social, da prática da tolerância, sem a qual, não se construirá uma sociedade pluralista, verdadeiramente democrática voltada ao respeito dos direitos e das liberdades fundamentais.

\section{THE HATE SPEECH, RIGHT AND DEMOCRACY}

\section{Abstract}

The purpose of this text is to analyze the hate speech in democratic society, as well as its implementatiom in several concrete cases in Brazil, the United States and the Inter-American Court of Human Rights. The objective is a general approach about its concept and the justifications why such discourse is incompatible with a plural, open and inclusive society.

Keyword: Hate Speech; Democracy; Tolerance.

\section{REFERENCIAS}

BARRETO, Vicente de Paulo: Tolerância. In.: Dicionário de Filosofia Política. Coordenador: Vicente de Paulo Barreto; Coordenador adjunto Alfredo Culleton. São Leopoldo RS: UNISINOS, 2010.

CASTELLS, Manuel. A Era da Informação: Economia, Sociedade e Cultura. v. III. Rio de Janeiro: Paz e Terra, 1999. 
GAY, Peter. O Cultivo do Ódio. Tradução de Sérgio de Paula e Viviane de Lamare Noronha. São Paulo: Companhia das Letras, 1995.

MIELKI, Ana Cláudia. Liberdade de expressão ou discurso de ódio? Disponível em: < http://www.cartacapital.com.br/blogs/intervozes/liberdade-de-expressao-ou-discurso-de-odio-2280.html>. Acesso em: 22 jun 2014.

SILVA, Júlio César Casarin Barroso. Democracia e Liberdade de Expressão: Contribuições para uma Interpretação Política da Liberdade da Palavra. Tese de Doutorado. São Paulo: USP, 2009.

ZELDIN. Theodore. Uma História Íntima da Humanidade. Tradução de Hélio Pólvora. Rio de Janeiro: Record, 1996.

Trabalho enviado em 15 de outubro de 2017.

Aceito em 26 de outubro de 2017. 